\title{
DUALITAS STIGMATISASI JANDA: REALITAS MASYARAKAT MINANGKABAU YANG MENDUA
}

\section{DUALITY OF THE WIDOW STIGMATIZATION: DUALISM REALITY OF MINANGKABAU SOCIETY}

\author{
Jelly \\ Universitas Andalas \\ Jln. Limau Manis Kecamatan Pauh, Kota Padang \\ jelly.bintidaimi@yahoo.co.id
}

Diterima tanggal 3 September 2018

Disetujui tanggal 26 Desember 2019

\begin{abstract}
This paper aims to express one form of dualism which is a fact in the social system of the Minangkabau society. The dualism which was originally termed by Saanin in 1989 as an illustration of the efforts of the Minangkabau society to balance religion and tradition appeared in the duality of society when faced with various situations and conditions. In this paper, researchers try to see the duality of the Minangkabau society through stigmatization of widows. These ambiguous views and attitudes can be seen from the stigmas built on widows. For example, the society considers that the widow "indak pandai balaki" (not care about her husband) but on the other hand widows considered as "kancang ka laki-laki" (wanton). The tool used to analyze data is the concept of duality. Through a dualistic analysis of the stigma of widows, researchers found that the Minangkabau society applied a system of duality in their lives.
\end{abstract}

Keywords: Minangkabau, stigma, widow, and duality.

\begin{abstract}
ABSTRAK
Tulisan ini bertujuan untuk mengungkap salah satu wujud dari dualisme yang merupakan fakta dalam sistem sosial masyarakat Minangkabau. Dualisme yang mulanya diistilahkan Saanin pada 1989 sebagai gambaran upaya masyarakat Minangkabau untuk menyeimbangkan agama dan adat ternyata muncul dalam sikap dualitas masyarakat ketika menghadapi berbagai situasi dan kondisi. Pada tulisan ini, peneliti mencoba melihat sikap dualitas masyarakat Minangkabau melalui stigmatisasi terhadap janda. Pandangan dan sikap yang mendua ini nampak dari stigma-stigma yang dibangun terhadap janda. Contohnya, masyarakat menganggap bahwa janda indak pandai balaki, tetapi disisi lain ia dianggap
\end{abstract}


kancang ka laki-laki. Alat yang digunakan untuk menganalisis data adalah konsep dualitas. Melalui analisis dualisme terhadap stigma mengenai janda, peneliti menemukan bahwa masyarakat Minangkabau menerapkan sistem dualitas dalam kehidupannya.

Kata kunci: Minangkabau, stigma, janda, dan dualitas.

\section{A. PENDAHULUAN}

Suatu kenyataan yang tidak bisa dipungkiri bahwa masyarakat Minangkabau menganut sistem kekerabatan matrilineal, artinya garis keturunan dan pewarisan suku diperoleh dari garis ibu. Dalam setiap aturan dan kegiatan adat perempuan Minangkabau menempati posisi yang penting. Menurut Arifin (2012: 30), dalam adat Minangkabau perempuan memiliki dua peran strategis yaitu sebagai aktor utama dan sebagai aktor pendamping. Bahkan novel dan cerita-cerita mengenai perempuan Minangkabau, juga merefleksikan bahwa kehidupan perempuan Minangkabau penuh dengan berbagai macam konflik (Asri, 2013).

Sebagai aktor utama perempuan Minangkabau menjadi pemilik setiap upacara adat, laki-laki hanya sebagai pengemban tugas, sedangkan sebagai aktor pendamping perempuan bertugas sebagai pihak yang memberikan legitimasi dalam upacara yang melibatkan laki-laki. Jadi dalam aturannya, perempuan Minangkabau memiliki posisi yang strategis sehingga di sisi manapun, hak-haknya tetap saja terlindungi. Hal ini karena perempuan bertugas meneruskan garis keturunan dan juga bertugas menjaga dan mengolah harta pusaka (Yazid, 2014: 29).

Selain berperan sebagai penjaga harta pusaka dan penerus garis keturunan, perempuan di Minangkabau juga "ditinggikan" dengan bukti bahwa ia berperan sebagai bundo kanduang (ibu kandung). Pada dasarnya setiap perempuan Minangkabau yang telah menikah langsung mendapatkan status sebagai bundo kanduang. Tetapi dalam setiap kaum ${ }^{1}$ dipilih seorang perempuan yang dituakan dan berperan sebagai bundo kanduang. Bundo kanduang yang dituakan inilah yang akan diminta dan didengar pendapatnya dalam kaum tersebut. Yazid (2014) menyebutkan bahwa dalam adat Minangkabau perempuan disebut dengan istilah bundo kanduang untuk menghormati, meninggikan, dan menghargai perempuan. Dalam adat Minangkabau perempuan ditempatkan dalam sosok yang dikagumi, dilindungi, dan dihormati.

\footnotetext{
${ }^{1}$ Kaum merupakan istilah dalam bahasa Minangkabau yang merujuk kepada kekerabatan dalam batasan klan. Kaum merupakan sekelompok orang yang memiliki garis keturunan yang sama dan memiliki harta pusaka bersama. Sehingga masing-masing anggota kaum terikat dengan hubungan kekerabatan.
} 
Dalam masyarakat Minangkabau, perempuan yang telah menikah dilabel dengan istilah "lah kanai di adaik" (sudah dikenai dengan adat). Maksud istilah ini yaitu jika seorang perempuan sudah menikah, maka ia akan diposisikan sebagai orang yang telah dewasa serta diikutkan dalam setiap perundingan dalam kaumnya. Perempuan yang belum menikah dan sudah menikah, memiliki posisi dan perlakuan yang berbeda dalam adat Minangkabau. Perempuan yang belum menikah hanya akan dianggap sebagai kemenakan bukan sebagai bundo kanduang. Menikah dalam adat Minangkabau merupakan tahapan pendewasaan baik secara psikologi maupun sosial, maka perempuan yang telah menikah "dibebani"dengan adat.

Status bundo kanduang didapatkan oleh seorang perempuan setelah menikah (Selasih, 1989). Statusnya sebagai bundo kanduang tidak akan hilang, walau perempuan tersebut bercerai atau ditinggal mati oleh suaminya. Perempuan yang telah menikah kemudian bercerai atau ditinggal mati oleh suaminya, umumnya akan diminta oleh keluarganya untuk menikah lagi. Walaupun memang pada kenyataannya, ada juga janda yang tidak mau dipaksa oleh keluarganya dan memilih untuk membesarkan anaknya sendiri. Hal ini karena dalam kaumnya, perempuan tersebut membutuhkan sumando dalam upacara pernikahan. Setiap kaum dalam adat Minangkabau membutuhkan sumando untuk berurusan dengan $\mathrm{kaum}$ lain dalam upacara pernikahan. Yunita (2012) mengatakan bahwa keberadaan suami walaupun rapuh tetap sangat dihormati dan dibutuhkan kaum istrinya.

Perempuan Minangkabau yang telah menjanda mempunyai dua pilihan yaitu menikah lagi atau fokus mengurus anaknya. Dua hal ini sebenarnya tidak ada yang memberatkan karena jika ia menikah lagi, maka laki-laki yang akan menjadi suaminya tidak perlu memikirkan janda dan anak-anaknya sebagai beban. Secara normatif, lakilaki yang akan menikahi janda di Minangkabau tidak perlu khawatir dengan beban ekonomi karena perempuan Minangkabau memiliki harta atau tanah pusako. Selain itu idealnya kebutuhan kemenakan menjadi tanggung jawab mamak, sehingga jika seorang perempuan menjanda, maka ia tidak akan terlalu memikirkan kebutuhan anaknya.

Dalam masyarakat Minangkabau seorang perempuan dianggap sebagai simbol keagungan sistem matrilineal (Sukmawati, 2006). Perempuan memiliki kekuasaan tetapi di saat yang sama perempuan juga mengemban tugas yang tidak mudah. Oleh karena itu, dalam kehidupan sehari-hari, perempuan Minangkabau juga banyak mengalami tekanan dalam mengemban tugasnya. Kekuasaan dan kewenangan yang dimiliki oleh perempuan Minangkabau tidak menjadikannya lepas dari tekanan. Dalam kehidupan sehari-hari, perempuan Minangkabau dihadapkan dengan tuntutan perannya 
Handep, Vol. 2, No. 1, Desember 2018

sebagai umbuik jaloo pusaran aia. Artinya, dia dianggap sebagai pusat dari kehidupan keluarga dan kehidupan bermasyarakat. Hal ini mencerminkan bahwa tuntutan yang dihadapkan bagi perempuan Minangkabau lebih banyak dari pada laki-laki. Hal ini karena dalam masyarakat Minangkabau, perempuan dianggap menjadi sumber solusi dan pemecah masalah. Anggapan tersebut menekan perempuan Minangkabau dalam setiap tindakan dan perkataannya.

Selain dianggap sebagai sumber solusi, perempuan Minangkabau juga dibebani dengan tuntutan sebagai perempuan yang ideal. Tuntutan ini memberikan tekanan dan menimbulkan peluang konflik dalam kehidupan sehari-hari. Tuntutan antara konsep ideal seorang perempuan dengan kenyataannya berpotensi menimbulkan konflik. Konflik yang timbul dalam kehidupan sehari-sehari memberikan ruang bagi terbentuknya stigmatisasi terhadap janda. Hal ini didukung oleh sifat masyarakat Minangkabau yang memang berpotensi memiliki konflik tetapi sekaligus memiliki nilai-nilai yang mampu meredam konflik (Arifin, 2014: 2). Kehadiran nilai-nilai yang berperan sebagai peredam konflik tadi, menjadikan stigmatisasi terhadap perempuan berada dalam ranah dualitas. Cara pandang masyarakat terhadap janda dipengaruhi oleh nilainilai yang ada dalam masyarakat Minangkabau.

Masyarakat Minangkabau adalah masyarakat yang dualitas (Arifin, 2014) yaitu masyarakat yang memakai konsep secara ambigu dan mendua dalam menerapkan aturan adat dalam kehidupan bermasyarakat. Salah satu contohnya adalah masyarakat Minangkabau memakai lareh Bodi Caniago yang memakai azas demokrasi dan di saat yang sama memakai lareh (kelarasan) Koto Piliang yang bercirikan aristrokrasi. Konsep inilah yang menjadi fondasi utama dalam artikel ini. Termasuk dengan cara masyarakat melihat dan memaknai janda. Janda merupakan seorang perempuan Minangkabau sekaligus sebagai bundo kanduang yang mewariskan garis keturunan. Akan tetapi, tanpa keberadaan suami, janda dianggap tidak memenuhi syarat untuk menerima semua hak-haknya sebagai perempuan Minangkabau yaitu kewenangan untuk memberikan suara dalam kaumnya. Hal ini karena masyarakat Minangkabau menjadikan agama dan adat sebagai sendi kehidupannya. Masyarakat Minangkabau menjadikan agama dan adat sebagai landasan utama dalam kehidupan sosial. Secara adat, perempuan yang tidak memiliki suami tidak dipersoalkan karena ia yang memegang otoritas dalam keluarga. Sebaliknya, dari pandangan agama Islam, laki-laki dianggap sebagai pelindung dan pelengkap kehidupan perempuan.

Agama dan adat menjadi dua fondasi yang membentuk cara pandang masyarakat Minangkabau. Dua landasan inilah yang membentuk cara 
pandang dualitas masyarakat terhadap berbagai hal, termasuk janda. Walaupun perempuan Minangkabau "bisa hidup" tanpa laki-laki dengan semua hak-hak istimewanya sebagai bagian dari masyarakat matrilineal, tetap saja hal tersebut dianggap "tercela" secara agama. Bagi masyarakat Minangkabau agama, merupakan salah satu fondasi penting dalam melaksanakan adat (Hakimy, 2001). Hal ini tercermin dari pepatah "adat basandi syara', syara' basandi kitabullah" (adat bersandar kepada agama dan agama bersandar kepada Alquran). Berdasarkan konsepsi ini, keberadaan laki-laki penting bagi perempuan Minangkabau (Kuneifi, 2005). Walaupun perempuan menjadi tonggak utama dalam kehidupan, tetap saja laki-laki menjadi faktor penting yang harus ada untuk mendampingi perempuan.

Dari pemaparan di atas, peneliti ingin mengungkapkan bahwa masyarakat Minangkabau menerapkan dualitas dalam kehidupannya. Karakter masyarakat Minangkabau yang dualitas memengaruhi bentuk-bentuk stigma terhadap janda. Bentuk-bentuk stigma terhadap janda akan dipengaruhi oleh nilai-nilai yang dibangun oleh masyarakat karena stigma dibangun dan dibentuk oleh masyarakat. Hal ini menjadikan dualitas stigma terhadap janda.

Stigma yang dibangun terhadap janda berada dalam ruang lingkup ambigu. Bentuk-bentuk stigmatisasi terhadap janda yang berbeda dalam masyarakat matrilineal dengan masyarakat patrilineal. Nilai-nilai yang ada dalam masyarakat matrilineal memengaruhi bentuk-bentuk stigma dan menghasilkan stigma yang ambigu. Stigmatisasi terhadap janda juga dipengaruhi oleh pola pemikiran masyarakat Minangkabau yang dualitas tersebut. Bahkan stigma yang dibangun oleh kaum perempuan Minangkabau terhadap janda menegaskan bahwa perempuan Minangkabau juga menerapkan dualitas dalam kehidupannya.

Tujuan utama penelitian ini yaitu untuk mengungkapkan bagaimana bentuk stigma masyarakat Minangkabau terhadap janda. Riset ini mengungkapkan proses terbentuknya stigma dalam masyarakat Minangkabau terhadap janda. Selain itu juga akan digambarkan proses terbentuknya stigma yang dihasilkan oleh nilai-nilai "ideal" seorang janda dalam masyarakat Minangkabau. Minangkabau memiliki kekhasan dan nilai-nilai tersendiri. Nilai-nilai tersebut disebut dengan nilai alua jo patuik. Nilai alua jo patuik menganggap bahwa seorang wanita tidak patuik jika tidak memiliki suami. Nilai tersebut pasti berpengaruh terhadap stigma yang mereka bentuk terhadap janda.

Kekhasan dan keunikan stigma masyarakat Minangkabau terhadap janda inilah yang coba peneliti sandingkan dengan pembentukan stigma. Apakah dengan nilai-nilai tersebut, mempengaruhi pembentukan stigma masyarakat terhadap janda. Jika iya, bagaimana bentuk stigma yang 
dipengaruhi oleh nilai-nilai masyarakat Minangkabau tersebut.

Setelah proses pembentukan stigma yang dipengaruhi oleh nilainilai masyarakat Minangkabau, maka akan ditemukan pola masyarakat Minangkabau dalam memberikan stigma terhadap janda. Peneliti ingin mengetahui apakah kekhasan masyarakat Minangkabau sebagai masyarakat yang dualitas memberikan pengaruh terhadap stigma mengenai janda.

Selain itu peneliti juga ingin mengungkapkan bahwa identitas masyarakat Minangkabau sebagai masyarakat yang dualitas juga terwujud dalam stigmatisasi terhadap janda. Dengan demikian, dapat dikatakan bahwa konsep dualitas masyarakat Minangkabau berlaku menyeluruh termasuk dalam hal stigmatisasi terhadap janda. Sikap mendua tidak hanya berlaku dalam tataran adat saja, tetapi juga dalam kehidupan sehari-hari. Stigmatisasi terhadap janda terjadi dalam kehidupan sehari-hari. Proses pembentukan stigma ini terbentuk karena pola relasi masyarakat dalam

\footnotetext{
2 Maota merupakan salah satu kebiasaan masyarakat Minangkabau. Kebiasaan ini yaitu membicarakan seseorang atau sekelompok orang mengenai suatu kisah atau peristiwa yang terjadi. Maota berbeda dengan bergunjing ataupun bergosip. Dalam maota hal-hal yang dibicarakan bisa saja halhal yang umum, dan hal tersebut dikaitkan dengan hal-hal atau peristiwa lain. Bergunjing ataupun bergosip lebih fokus membicarakan seserorang atau sekelompok orang yang mengalami suatu peristiwa tanpa mengaitkannya dengan peristiwa lain.
}

kehidupan sehari-hari. Salah satu pola relasi tersebut adalah maota ${ }^{2}$.

Stigmatisasi terhadap janda merupakan konstruksi sosial dari nilai-nilai budaya yang ada dalam masyarakat. Atribut atau kategorikategori yang diberikan kepada janda dikonstruksi oleh nilai-nilai budaya dan akhirnya menghasilkan stigmatisasi terhadap janda (Goffman, 1963). Hal ini mencerminkan bahwa bentuk-bentuk stigma yang terbentuk terhadap janda mencerminkan masyarakat tersebut. Bentuk-bentuk stigma janda pastilah mencerminkan nilai-nilai yang ada dalam masyarakat, karena stigma tersebut dikonstruksi oleh nilai-nilai tersebut.

Dengan menganalisis dan mengungkapkan stigmatisasi terhadap janda, peneliti ingin mengungkapkan bahwa masyarakat Minangkabau adalah masyarakat yang dualitas. Pandangan dualitas terwujud dalam bentuk-bentuk stigma terhadap janda. Dengan melihat stigma terhadap janda, peneliti mencoba mengungkapkan karakter dualitas masyarakat Minangkabau di Kelurahan Korong Gadang. Stigma tersebut dibentuk melalui kebiasaan tuturan lisan yang disebut dengan maota. Melalui tuturan lisan, masyarakat Minangkabau di Kelurahan Korong Gadang membentuk stigma terhadap janda dan dengan mengemukakan stigma, dapat ditemukan pola bahwa karakter masyarakat Minangkabau di Kelurahan Korong Gadang memengaruhi pembentukan stigma terhadap janda. 
Hal ini karena tuturan lisan masyarakat mencerminkan identitas dan pikiran masyarakat (Kapferer, 1990).

Penelitian ini dilakukan terhadap masyarakat Minangkabau pada bulan Mei 2017 sampai dengan Maret 2018 di Kelurahan Korong Gadang Kecamatan Kuranji Kota Padang. Penelitian ini merupakan penelitian kualitatif dengan metode pemilihan informan purposive sampling. Hal ini diterapkan karena harus ada kriteria yang peneliti tetapkan untuk memilih informan. Kriteria utama yang peneliti tentukan yaitu informan haruslah seorang perempuan yang telah menikah, kemudian menjadi janda.

\section{B. HASIL DAN BAHASAN}

\section{Stigmatisasi Janda Dalam Masyarakat Minangkabau}

Berdasarkan pemaparan di atas, janda dalam masyarakat Minangkabau mengalami stigmatisasi. Menurut Hurlock (1980) stigmatisasi terhadap janda dibangun oleh masyarakat karena anggapan yang merendahkan perempuan dan mengangungkan laki-laki. Karena keberadaan laki-laki dalam masyarakat patrilineal dianggap agung maka banyak pelecehan dan perendahan terhadap kaum perempuan. Salah satunya di India perempuan dianggap pantas mati jika suaminya meninggal dunia. Bahkan di beberapa negara perempuan yang menjanda kehilangan hak-haknya sebagai seorang perempuan.

Uniknya, dalam masyarakat Minangkabau yang menganut sistem matrilineal juga terjadi stigmatisasi terhadap janda. Keberadaan adat dan agama yang saling melengkapi membuat stigmatisasi terhadap janda berbeda dengan yang dialami oleh masyarakat patrilineal. Dalam masyarakat patrilineal janda dianggap rendah karena ia dianggap tidak berdaya jika tidak ada laki-laki, maka dalam masyarakat Minangkabau janda dianggap berbeda dengan perempuan lainnya karena tidak memiliki suami. Hal ini yang memicu munculnya stigmatisasi terhadap janda dalam masyarakat Minangkabau.

Masyarakat Minangkabau menganggap penting simbol persamaan yang dianggap mengikat perbedaan. Hal ini dibuktikan dengan konsepsi urang awak dalam berhubungan dengan sesuatu yang berada di luar dirinya. Mereka akan mengatakan bahwa seseorang sebagai urang awak ketika membicarakan orang lain yang dianggap sama (sesama masyarakat Minangkabau). Hal ini membuktikan bahwa berbeda bukanlah hal yang bisa diterima begitu saja dalam masyarakat Minangkabau.

Masyarakat Minangkabau di Kelurahan Korong Gadang menganggap Janda berbeda dengan perempuan yang memiliki suami, sehingga janda mengalami stigmatisasi. Ia dianggap berbeda karena keberadaan suami sangat penting bagi perempuan Minangkabau yang disebut dengan istilah sumando. Karena janda tidak memiliki suami, maka ia dianggap tidak lengkap secara adat karena tidak 
Handep, Vol. 2, No. 1, Desember 2018

memiliki suami yang akan diposisikan sebagai seorang sumando.

Perempuan merupakan pemegang kekuasaan dan garis keturunan di Minangkabau. Posisi ini memungkinkan perempuan Minangkabau memiliki kewenangan untuk menciptakan stigmatisasi terhadap janda. Perempuan Minangkabau membangun stigmatisasi terhadap janda karena mereka menganggap perempuan yang tidak memiliki suami berbeda dengan mereka. Karena tidak memiliki suami yang dalam kaumnya disebut dengan urang sumando, janda dianggap berbeda dengan perempuan lainnya. Perbedaan inilah yang melatarbelakangi munculnya stigma terhadap janda dalam masyarakat Minangkabau.

Ada berbagai macam stigma terhadap janda, salah satunya dikaitkan dengan seksualitas (Parker, 2016). Dalam masyarakat Minangkabau stigmatisasi terhadap janda dibangun oleh masyarakat berdasarkan nilai-nilai kesopanan yang mereka yakini. Janda selalu dicurigai dan dianggap tidak sopan karena status mereka. Jika janda dekat dengan laki-laki, maka mereka dianggap gata (genit) dan jangak (centil). Akan tetapi, jika mereka mendiri, maka akan dianggap tagak surang.

Stigma terhadap janda di Minangkabau berbeda dengan yang terjadi dalam masyarakat patrilineal. Dalam masyarakat matrilineal, perempuan menjadi sentral kekuasaan dan semua perkataan dan tindakannya dianggap memiliki pengaruh (Yazid,
2014). Dalam keseharian, kaum perempuanlah yang menciptakan dan membangun stigmatisasi terhadap janda. Stigmatisasi terhadap janda didukung oleh kebiasaan perempuan Minangkabau yang suka maota. Masyarakat Minangkabau khususnya perempuan menjadikan maota sebagai kegiatan dan kebiasaan mereka seharihari.

\section{Kebiasaan Maota dan Stigmatisasi Janda}

Maota merupakan kebiasaan yang lumrah bagi masyarakat Minangkabau secara umum. Masyarakat Minangkabau mewarisi budaya tutur/lisan dalam sendi kehidupannya (Sukmawati, 2006). Bahkan sejarah Adat Alam Minangkabau yang disebut tambo diwariskan dalam bentuk lisan, bukan dalam bentuk tertulis. Semua petatah dan petitih adat Minangkabau juga diwariskan dalam bentuk lisan dari satu generasi ke generasi selanjutnya. Walaupun saat ini sudah ada dalam bentuk tertulis, itu merupakan budaya lisan yang dituliskan.

Berdasarkan hal tersebut, maka sampai saat ini maota masih menjadi ciri khas masyarakat Minangkabau. Kebiasaan masyarakat Minangkabau yang suka maota memengaruhi berbagai sendi kehidupan. Maota merupakan kebiasaan yang juga memengaruhi pola relasi dan hubungan sosial antarmasyarakat Minangkabau. Dalam praktiknya, kebiasaan maota dapat dilakukan di mana saja. Ketika 
di tempat kerja mereka akan maota dan menceritakan berbagai hal yang mereka ketahui. Bahkan dalam kehidupan sosial, maota menjadi kebiasaan harian masyarakat Minangkabau. Hal ini yang disebut oleh Kalmre (2017) sebagai rumours. Sebagaimana halnya dengan maota, menurut Kalmre (2013) romours merupakan sarana dalam membentuk pandangan sosial dan kebiasaan. Bahkan, romuors juga bisa membentuk legenda dan sejarah umat manusia. Jika dilihat dari tujuan dan fungsi rumours, maka maota juga memiliki fungsi yang kurang lebih sama.

Bagi masyarakat Minangkabau maota merupakan suatu sarana dalam membentuk opini publik, bahkan bisa membuat stigma yang melekat terhadap janda. Maota merupakan salah satu wujud budaya lisan masyarakat Minangkabau yang bahkan sejarah dan tambo alam Minangkabau juga diwariskan dengan tuturan. Begitu kuat keberadaan budaya tutur dalam masyarakat Minangkabau, sehingga tidak mengherankan jika budaya lisan (maota) tersebut juga mampu menghadirkan stigma terhadap janda. Bahkan Shibutani (1966) menyatakan bahwa budaya lisan masyarakat mampu merepresentasikan kepercayaan dan apa yang dipikirkan oleh masyarakat. Bahkan budaya lisan mampu menghadirkan apa yang tersembunyi dan mengemukakan sisi lain dari masyarakat yang bersangkutan.

Kalmre (2013) juga mengatakan bahwa budaya lisan juga menjadi bagian dari identitas seseorang bahkan sebuah bangsa. Maota merupakan identitas dan ciri khas masyarakat Minangkabau. Ketika melakukan penelitian, peneliti sering menemui masyarakat Minangkabau khususnya di Kelurahan Korong Gadang bergunjing dan maota mengenai janda. Mereka menjadikan janda sebagai bahan ota karena berbagai alasan. Maota merupakan salah satu bentuk budaya tutur atau lisan masyarakat Minangkabau. Seperti yang peneliti jelaskan sebelumnya maota berbeda dengan bergunjing atau bergosip. Maota merupakan kegiatan memperbincangkan berbagai hal.

Tidak ada hal spesifik atau khusus yang dbicarakan. Maota mencakup halhal umum dan khusus. Mulai dari ranah politik yang bersifat umum hingga ranah keluarga yang bersifat khusus. Sementara itu bergunjing atau bergosip merupakan lanjutan dari aktivitas maota. Bergunjing atau bergosip lebih fokus membicarakan tentang seseorang atau sebuah peristiwa.

Kebiasaan maota masyarakat bisa mengangkat tema apa saja dan di dalamnya mencerminkan isu yang beredar dalam masyarakat. Inilah yang dimaksud oleh Goldstein (2004) bahwa budaya lisan masyarakat mencerminkan apa yang terjadi, apa yang dipikirkan, dan apa yang diharapkan oleh masyarakat. Tuturantuturan masyarakat merupakan refleksi dari dialog yang terjadi di dalam masyarakat. 
Dengan mencermati kebiasaan maota masyarakat, maka akan membuat peneliti paham apa yang dipikirkan masyarakat mengenai janda. Masyarakat menganggap bahwa janda akan selalu terobsesi dengan seksualitas jika sudah mencobanya, bahkan jika ia dijaga oleh nilai-nilai budaya dan agama sekalipun, tetap saja perempuan dianggap butuh dengan hal tersebut. Hal ini seperti yang diungkapkan oleh $\mathrm{TR}^{3}$

"Janda akan selalu menginginkan untuk dekat dengan laki-laki. Karena memang sudah fitrahnya janda untuk mencari perhatian dari lawan jenisnya. Janda itu kan sudah pernah mencoba hubungan seksual sekali, jadi dia akan selalu menginginkannnya. Itu sudah pasti. Bagaimanapun kuatnya agamanya tetap saja janda itu perempuan yang haus akan seksualitas" (wawancara TR, Padang, 20 Mei 2017).

Salah satu sarana yang membangun stigmatisasi terhadap janda adalah mata. Dengan budaya tutur masyarakat ini stigma terhadap janda beredar dan bertahan dalam masyarakat. Maota merupakan salah satu sarana pembentukan stigma terhadap janda dalam masyarakat Minangkabau di Kelurahan Korong Gadang. Dengan maota masyarakat menyebarkan pandangan mereka terhadap janda dan memengaruhi orang

\footnotetext{
${ }^{3}$ TR merupakan salah seorang kerabat janda yang ada di Kelurahan Korong Gadang. Saat ini TR berusia 47 tahun dan berprofesi sebagai seorang pedagang di Padang.
}

lain untuk memiliki pandangan yang sama. Melalui maota masyarakat Minangkabau di Kelurahan Korong Gadang memengaruhi opini publik mengenai janda.

Alasan utama kebiasaan maota bisa mempengaruhi pandangan dan opini publik karena dilakukan setiap hari. Maota dilakukan disela-sela rutinitas harian. Dengan demikian, perlahan tapi pasti pandangan masyarakat akan diarahkan untuk menyetujui dan mengikuti pendapat orang banyak. Maota dilakukan sebagai selingan dari rutinitas harian dan dilakukan secara terus menerus. Masyarakat secara tidak sadar akan mengikuti pendapat dan pandangan orang lain tanpa merasa perlu untuk mengklarifikasinya terlebih dahulu. Situasi dan kondisi seperti inilah yang menyebabkan stigmatisasi mengenai janda mudah terbentuk.

\section{Dualitas Stigma Janda Dalam Masyarakat Minangkabau di Kelurahan Korong Gadang \\ Undang-undang perkawinan No. 1} tahun 1974 pasal 38 menyatakan bahwa perkawinan dapat putus karena kematian, perceraian dan atas keputusan pengadilan dalam hal ini kompilasi hukum Islam mensyaratkan bahwa ikrar suami untuk bercerai dianggap sah jika dilakukan di sidang pengadilan agama. Ini adalah ketentuan yang ditetapkan dalam kompilasi hukum Islam mengenai perkawinan. Ketetapan tersebut berbeda dengan pemahaman masyarakat Minangkabau di Kelurahan Korong Gadang. 
Masyarakat di Kelurahan Korong Gadang menganggap bahwa perceraian tetap sah walaupun hanya diucapkan oleh suami tanpa ada saksi. Bahkan masyarakat menganggap bahwa perceraian tetap sah jika suami meninggalkan istrinya selama dua bulan tanpa ada berita dan keterangan ataupun janji untuk kembali.

Dengan situasi tersebut, ada begitu banyak janda yang bercerai secara tidak resmi di Kelurahan Korong Gadang. Masyarakat memberikan pandangan yang sama terhadap janda yang bercerai secara resmi maupun tidak. Mereka menjadi bahan pergunjingan di berbagai tempat. Baik di sawah pada pagi hari, maupun di rumah-rumah pada sore hari. Melalui pengamatan mengenai maota, peneliti menemukan stigma terhadap janda oleh masyarakat Kelurahan Korong Gadang.

Peneliti menemukan bahwa masyarakat Minangkabau di Kelurahan Korong Gadang membangun sikap dualitas dalam membentuk stigma mengenai janda. Hal ini karena ketika membangun pandangan dan stigma mereka terhadap janda, masyarakat menunjukkan sikap mendua. Di satu sisi masyarakat mengungkapkan kecurigaannya terhadap janda, tetapi disisi yang lain mereka juga mengungkapkan kekaguman mereka terhadap janda. Seperti yang diungkapkan oleh $\mathrm{AB}^{4}$ berikut ini:

\footnotetext{
${ }^{4} \mathrm{AB}$ merupakan salah seorang masyarakat Kelurahan Korong Gadang yang berusia 45 tahun dan bekerja sebagai petani.
}

"Si RM tu karajonyo ndak adoh yang batua tu doh, pai jo laki-laki se taruih mah, namonyo jando lah, kama lo nyo ka cari pitih lai, tapi jando bana nyo, lai ndak mamintak ${ }^{5}$ nyo ka amak e lai doh, kok ka mamintak nyo ka amake, jo a lah ka nyo agiah dek ni Darih tu" (wawancara AB, Padang, 29 Mei 2017).

(Sikap dan perilaku RM memang tidak ada yang benar. Dia selalu saja pergi dengan laki-laki. Yah mau bagaimana lagi, dia kan janda. Dia kan butuh uang. Tetapi walaupun dia janda, dia tidak meminta uang kepada orang tuanya. Kalau dia meminta uang kepada orang tuanya, darimana orang tuanya mendapatkan uang).

Itu adalah salah satu pandangan dan ungkapan masyarakat terhadap janda muda. Mereka menganggap bahwa janda muda pasti sering pergi dengan laki-laki. Bahkan masyarakat mengatakan bahwa janda akan selalu melakukan perbuatan yang tidak benar. Ketika masyarakat mengatakan "dia itu kan janda" seolah-olah sikap buruk dan negatif selalu melekat dengan janda. Tetapi pada saat yang sama mereka juga mengatakan bahwa janda adalah orang yang mandiri. Hal ini nampak dari ungkapan masyarakat yang mengatakan "tetapi walaupun dia janda, dia tidak meminta uang kepada orang

\footnotetext{
${ }^{5}$ Lai ndak mamintak ka urang tuo (tidak meminta uang kepada orang tuanya) mencerminkan ungkapan kekaguman terhadap janda. Janda dianggap pribadi yang mandiri sehingga tidak meminta uang atau menggantungkan hidup kepada orang tuanya.
} 
Handep, Vol. 2, No. 1, Desember 2018

tuanya". Ungkapan ini mencerminkan kekaguman masyarakat bahwa walaupun janda seorang yang dianggap melakukan hal-hal yang tidak benar, tetapi tetap saja janda dalam masyarakat Minangkabau adalah pribadi yang mandiri.

Hal yang sama tetapi dalam redaksi yang berbeda juga diungkapkan oleh $\mathrm{MT}^{6}$ mengenai saudarinya $\mathrm{RA}^{7}$ yang menjadi janda dua kali.

"Yah, mau bagaimana lagi, kalau sudah salah dari awal itu memang sampai akhir akan tetap salah. Makanya seharusnya setiap istri itu harus bertahan dengan sekuat tenaga untuk mempertahankan suami pertama. Kalau sudah bercerai tidak ada harapan. Sedangkan ada suami saja saudari saya itu tidak pandai menjaga diri, apalagi ketika ia sudah menjadi janda. Nalurinya pasti akan mencari laki-laki lain. Itu sudah hukum alamnya. Tetapi saya tetap saja salut dengan sikapnya yang tegar dalam membesarkan anak. Ia berjualan untuk menghidupi anaknya, tetapi tetap saja dia harus menikah agar masa depan ia dan anaknya terjamin. Kalau kami mana bisa membantunya, hidup kami saja sudah susah"

\footnotetext{
${ }^{6}$ MT merupakan sepupu RA. MT bekerja sebagai Ibu rumah tangga. Saat ini usia MT 32 tahun dan sudah memiliki anak satu orang.

${ }^{7}$ RA berusia 34 tahun dan saat ini bekerja sebagai penjual makanan kecil seperti bakwan, tahu goreng dan makanan ringan di sebuah sekolah. RA dua tahun lebih tua dari MT dan sudah memiliki anak 2 orang.
}

(wawancara MT, Padang, 30

Agustus 2017).

Berikut adalah penjelasan dan pembahasan bentuk dualitas stigma terhadap janda dalam masyarakat Minangkabau. Masyarakat Kelurahan Korong Gadang menganggap janda sebagai beban yang harus dipikul dan ditanggung oleh keluarga luasnya. Dalam banyak kesempatan, peneliti menemukan banyak di antara keluarga janda yang memaksanya menikah kembali.

Alasan utama mereka yaitu mereka ingin agar janda memiliki kehidupan yang lebih baik. Jika janda menikah, maka keluarganya tidak akan pusing lagi memikirkan finansial dan statusnya sebagai janda. Sebenarnya menjaga dan membesarkan anak merupakan bagian dari tanggung jawab keluarga luas dan mamak, tetapi karena tanah pusaka semakin berkurang sehingga mamak dan keluarga luas merasa berat untuk memikul tanggung jawab tersebut. Berbagai stigma dimunculkan oleh keluarga dengan cara maotaan janda kepada orang lain. Sikap mereka tersebut akhirnya menjadi doksa atau pembenaran untuk menikahkan janda. Menikah kembali menjadi satu-satunya pilihan yang dianggap aman. Dengan menikahkan saudara atau kerabat mereka yang janda membuat janda tidak lagi menjadi tanggungan keluarga luas.

Kejadian ini sering peneliti temui di lapangan. Bahkan ada keluarganya yang bertengkar dengan janda karena masalah ini. Hal ini membuktikan 
bahwa keluarga janda menganggap mereka sebagai beban. Beban yang harus mereka pikul karena janda tidak lagi memiliki suami. Dengan menikah kembali, keluarga janda merasa tidak lagi memiliki tanggung jawab. Hal ini terjadi secara umum dalam masyarakat Minangkabau di Kelurahan Korong Gadang.

Di sisi lain masyarakat juga menganggap bahwa janda adalah pribadi yang mandiri yang diistilahkan dengan tagak surang. Tagak surang dalam masyarakat Minangkabau berarti berdiri sendiri yang mengacu kepada sikap mandiri. Janda dianggap pribadi yang mandiri dan mampu memenuhi kebutuhan hidupnya. Bahkan janda merupakan prioritas utama dalam keluarga luas untuk mengolah tanah pusaka. Oleh karena itu, janda dianggap mampu memenuhi kebutuhan hidupnya sendiri.

Hal ini terbukti dari celetukanceletukan masyarakat (wawancara dengan informan, Padang, 25 Mei 2017) ketika maota mengenai janda “awak yo salut wak jo $A D^{8}$ ko, nyo jando, anak e banyak, jo ka sawah urag anak e nyo iduik an ne" ( kami salut dengan $\mathrm{AD}$, dia janda dan memiliki banyak anak, tetapi dia bisa menghidupi anaknya dengan bekerja di sawah orang lain). Hal ini membuktikan bahwa

8 AD merupakan salah seorang janda yang memiliki sebelas orang anak. Saat ini AD berusia 49 tahun dan ia bekerja sebagai buruh tani untuk menghidupi anak-anaknya. Hubungan AD dan kerabatnya tidak berjalan dengan baik. keluarganya juga salut dengan kehidupan AD yang keras, hidup sebagai janda dan memiliki banyak anak, tetapi tetap saja ia bekerja keras menghidupi anaknya.

Hal ini bertentangan dengan pandangan masyarakat sebelumnya yang menyatakan bahwa janda menjadi beban dalam keluarga. Ketika stigmatisasi terhadap janda dibentuk sebagai beban bagi keluarga, tetapi di saat yang sama tercipta juga pandangan yang mengatakan bahwa janda adalah perempuan yang mandiri. Hal inilah yang peneliti sebut dengan dualitas stigma masyarakat terhadap janda. Melalui maota, masyarakat Minangkabau membangun pandangan yang mendua terhadap janda. Pandangan ini mereka ungkapkan dan sebarkan kepada orang lain, sehingga dalam prosesnya stigma mengalami proses tarik menarik antara positif dan negatif. Masyarakat membangun stigma negatif sekaligus positif dalam waktu yang bersamaan.

Peneliti menemukan bahwa pandangan dan sikap masyarakat terhadap janda memiliki dua posisi. Posisi pertama masyarakat memandang janda sebagai sebuah status. Masyarakat membangun stigma yang negatif terhadap janda terkait dengan statusnya. Pandangan yang kedua, masyarakat memandang janda sebagai individu. Hal ini membangun stigma yang positif terhadap janda karena sebagai individu yang dikenal oleh masyarakat, janda merupakan pekerja keras dan wanita yang mandiri. Jika masyarakat melihat 
Handep, Vol. 2, No. 1, Desember 2018

dari statusnya, maka akan terbentuk stigma negatif, tetapi jika dilihat dari sisi janda sebagai individu atau perempuan Minangkabau yang tercipta adalah stigma positif. Dua hal ini saling terkait dan terikat satu sama lain. Dengan pandangan ini membuat perbedaan yang mendasar dalam pembentukan stigma terhadap janda.

Hal ini terbukti dari percakapan $\mathrm{TR}^{9}$ dan $\mathrm{MH}^{10}$ di suatu sore mengenai $\mathrm{EW}^{11}$ (wawancara TR; $\mathrm{MH}$, Padang, 25 Mei 2017. EW merupakan seorang janda yang ditinggal mati oleh suaminya. EW dianggap sebagai janda yang tidak nakal dan selalu tenang. Ia dianggap janda yang ideal karena tidak mencolok dan tidak banyak menimbulkan masalah. Bahkan EW juga dianggap sebagai perempuan yang bekerja keras dan tagak surang karena memang ia tidak mau menikah lagi. EW memfokuskan kehidupannya

\footnotetext{
9 TR merupakan ipar dari EW. Saat ini TR berusia 38 tahun dan bekerja sebagai pedagang di kantin salah satu SMP yang ada di Kelurahan Korong Gadang.

${ }^{10} \mathrm{MH}$ adalah sepupu TR, jadi MH masih ada hubungan ipar dengan EW. MH berusia 40 tahun dan lebih tua dua (2) tahun dari TR. Berbeda dengan TR, hubungan MH dan EW tidak begitu baik. TR bekerja sebagai petani dan memiliki ladang yang luas.

${ }^{11}$ EW merupakan janda yang ditinggal mati oleh suaminya. Suami EW yaitu IR yang sudah meninggal dunia merupakan kakak dari TR dan sepupu dari MH. Sehingga hubungan EW dengan TR dan MH adalah saudara ipar. Setelah suaminya meninggal dunia, EW bekerja sebagai penjual bakwan yang dititipkan ke warung-warung sekaligus menanam sayur di tanah yang ditinggalkan oleh almarhum suaminya.
}

untuk membesarkan anak-anaknya. Masyarakat menyebut EW sebagai janda tanang aia yang berarti tidak banyak menimbulkan masalah.

Dengan kondisi tersebut, tetap saja EW menjadi bahan ota masyarakat. Mereka mengatakan bahwa EW tenang tetapi tetap saja tidak bisa dipercaya. EW tetap saja dicurigai melakukan perbuatan yang "nakal" atau berpotensi mengganggu suami orang lain. Walaupun EW sudah bersikap baik dan bahkan digelari dengan janda setenang air tetap saja masyarakat menganggap EW sebagai sebuah ancaman. Masyarakat terutama tetangga EW tetap saja menganggap EW berpotensi mengganggu atau bahkan "merebut" suami mereka. Jadi menurut masyarakat tidak ada jaminan EW tidak akan berbuat hal yang "nakal" walaupun ia terlihat tenang dan tidak banyak tingkah. Hal ini terlihat dari percakapan berikut:

"Memang EW tenang-tenang saja, tidak banyak parangai dan tidak banyak ulah. Bahkan tanah peninggalan suaminya itu ia gunakan untuk menghidupi anakanaknya. Ada orang yang mau meminangnya, dia tetap tidak mau. Dia tenang-tenang saja. Tidak banyak menyusahkan orang lain, tapi bagaimanapun kita tetap tidak bisa percaya seratus persen terhadapnya. Dia itu kan janda, jadi pasti ada yang dia sembunyikan. Pasti dia ingin dekatdekat dengan laki-laki. Mana ada janda yang tidak merindukan lakilaki. Kalau ada laki-laki yang dia 
inginkan maka dia akan "lasak" juga" (wawancara informan, Padang, 25 Juni 2017).

Dari hal tersebut peneliti melihat bahwa masyarakat memandang janda dalam kaca mata mendua. Di satu sisi dia dianggap tanang, tetapi di sisi lain dia juga dianggap lasak ${ }^{12}$. Menurut analisa peneliti, masyarakat membagi dua kategori stigma mereka terhadap janda, yaitu dari sisi individu dan status. Masyarakat akan mengatakan salut dan menganggap janda yang mampu menghidupi anaknya adalah individu yang mandiri. Di sisi lain, masyarakat juga akan menganggap janda juga sebagai ancaman terkait dengan statusnya sebagai seorang perempuan tanpa suami. Jadi, dualitas stigma yang dibangun terhadap janda berasal dari dua cara pandang ini.

Contoh dualitas stigma terhadap janda yang lainnya yaitu indak pandai balaki dan kancang ka laki-laki. Masyarakat Minangkabau membangun stigma bahwa janda adalah seorang perempuan yang tidak pandai mengurus suaminya. Ia dianggap tidak pandai menyenangkan dan mengurus keperluan suaminya, sehingga pernikahannya berakhir dengan perceraian. Hal ini mengindikasikan bahwa janda

${ }^{12}$ Lasak bisa diartikan dengan gesit tetapi biasanya sering dikaitkan dengan konotasi negatif. Lasak biasanya diungkapkan untuk menyatakan sifat seseorang yang tidak bisa tenang dan selalu melakukan banyak pekerjaan. Lasak merupakan anonim dari kata tenang. membangun hubungan yang buruk terhadap laki-laki atau mantan suaminya. Di sisi lain, ketika seorang perempuan menjadi janda, ia juga dilabel dengan kancang ka laki-laki, berarti ia sangat menginginkan hubungan yang dekat dengan laki-laki. Dua hal ini sangat bertentangan tetapi tidak dapat dipisahkan dalam kehidupan janda.

Hal ini terlihat dari percakapan antara percakapan antara SLV dan EN mengenai $\mathrm{UM}^{13}$ (wawancara informan, Padang, 18 Februari 2018):

SLV : "Bukan salah $\mathrm{BN}^{14}$ jika mereka bercerai. UM tidak pernah tahu dengan laki-laki. Dia tidak pandai membaca apa yang dinginkan oleh laki-laki. Tidak ada laki-laki yang mau dihardik oleh istrinya di depan umum."

EN : "Iya saya sering melihat UM itu bahkan tidak pandai berhias diri, mana ada laki-laki yang mau dengan perempuan yang gemuk dan tidak pandai mengurus diri dan suami."

SLV : "Sekarang dia sudah janda, siapa yang mau dengannya, sudahlah ia gemuk dan tidak pandai pula

\footnotetext{
${ }^{13}$ SLV, EN merupakan seorang ibu rumah tangga yang tidak bekerja. SLV berusia 45 tahun dan EN 49 tahun. Sehari-hari SLV dan EN sering berkumpul bersama setiap pagi ketika berbelanja bahan-bahan masak. SLV, EN dan teman-temannya sering berkumpul dan maota di kedai dari pagi sampai tengah hari. Aktivitas tersebut memberikan peluang terbentuknya stigma terhadap janda.

${ }^{14} \mathrm{BN}$ merupakan mantan suami UM yang saat ini berusia 45 tahun dan bekerja sebagai buruh.
} 
Handep, Vol. 2, No. 1, Desember 2018

mengurus suami. Dia tidak pandai membaca apa yang diinginkan oleh laki-laki terhadap perempuan. Laki-laki manapun tidak akan betah dengannya."

EN : "Tetapi sekarang dia sedang dekat dengan laki si PM. Galak manih nyo ka kancang ka laki-laki (dia pandai bermanis mulu dan bermanis muka dengan laki-laki) sekarang. Tidak tanggungtanggung bahkan ia pandai sekali menggoda laki-laki dengan merasa sok cantik. Kalau ada laki-laki maka dia akan sering tertawa dan membuat lelucon yang tidak lucu sehingga laki-laki akan tertarik dan betah berlamalama dengannya."

Dari percakapan tersebut dapat dilihat bahwa terdapat dua pandangan yang berbeda terhadap UM. Di satu sisi UM dianggap tidak pandai mengurus suami dan tidak mampu mengetahui pikiran dan apa yang diinginkan oleh laki-laki. UM dianggap perempuan yang tidak pandai berhias dan tidak cantik, sehingga ia tidak pandai membaca apa yang diinginkan oleh laki-laki yaitu kecantikan dari seorang perempuan. UM dianggap tidak peka dan tidak mampu mengetahui hal tersebut. Bahkan masyarakat menganggap bahwa inilah kelemahannya dan penyebab UM bercerai. Tetapi di sisi lain, setelah bercerai dan memiliki status janda, tiba-tiba saja UM dianggap sebagai perempuan yang mampu menarik laki-laki dengan senyumnya. Semua tingkah UM dianggap merupakan taktik yang dilakukan oleh UM untuk menarik kaum laki-laki. Uniknya UM dianggap "berhasil" membuat laki-laki merasa betah dengannya. Padahal sebelum menjadi janda, UM dianggap sebagai perempuan yang tidak peka terhadap apa yang diinginkan oleh laki-laki.

Menurut peneliti, hal ini terjadi karena dua pandangan masyarakat terhadap janda, yaitu perilaku dan status janda. Jika masyarakat melihat sikap dan perilaku UM, maka ia dianggap sebagai perempuan yang tidak diinginkan laki-laki karena tidak mampu mengetahui apa yang diinginkan oleh laki-laki. Akan tetapi, jika melihat dari sisi status UM sebagai seorang janda, maka tiba-tiba saja UM dianggap sebagai wanita yang mampu menarik laki-laki untuk betah berlamalama dengannya. UM dianggap mampu bermanis mulut dan mampu menggoda laki-laki. Tentu saja pandangan ini muncul karena masyarakat melihat dari sisi status UM sebagai janda. Dengan statusnya tersebut, ia dianggap mampu menggoda laki-laki, padahal masyarakat mengatakan bahwa perceraian UM terjadi karena ia tidak mampu mengetahui apa yang diinginkan oleh laki-laki.

Dua pandangan yang sangat bertentangan tersebut dipercaya masyarakat cenderung dimiliki oleh setiap janda. Janda dianggap indak pandai balaki dalam kaitannya dengan mantan suaminya, tetapi dianggap kancang ka laki-laki jika dilihat dari hubungannya dengan laki-laki lain. 
Ketika masyarakat membicarakan mantan suami janda, maka akan terbesit sosok janda yang tidak bisa mengurus suami dan menyebabkan perceraian rumah tangga. Jika melihat hubungan janda dengan laki-laki lain, maka masyarakat akan beranggapan bahwa janda kancang ka laki-laki karena mereka melihat banyak laki-laki yang ingin dekat dengan janda.

Dua pandangan ini akan selalu melekat terhadap janda. Hal ini mencerminkan bahwa masyarakat Minangkabau melihat dari dua sisi. Sikap seperti inilah yang menyebabkan stigma terhadap janda di Minangkabau berbeda dengan masyarakat lainnya. Dalam masyarakat patriarkat, janda cenderung hanya menerima stigma negatif. Stigma berupa pelecehan atau pernyataan merendahkan terutama dalam hal-hal yang berkaitan dengan seks karena status tersebut (Parker, 2016).

Menurut peneliti, dualitas stigma ini mencerminkan sikap masyarakat Minangkabau. Hal ini karena budaya tutur masyarakat (salah satunya adalah maota), mencerminkan pikiran dan pengetahuan masyarakat. Karakter suatu masyarakat bisa dilihat dari budaya tuturnya atau budaya lisannya. Masyarakat Minangkabau lebih banyak membuat pandangan yang mendua dalam maotaan janda. Realitas tersebut menunjukkan stigma yang mendua sebagai cerminan sikap dualitas masyarakat Minangkabau.

Sebagai salah satu sarana pembentuk stigma, maota merupakan kebiasaan masyarakat Minangkabau. Kegiatan ini bisa dijumpai di manapun dan kapanpun di dalam masyarakat. Dengan mencermati kegiatan maota, dapat diketahui bagaimana pandangan masyarakat terhadap janda. Pendapat yang mereka ceritakan adalah pandangan-pandangan yang mendua. Baik disadari atau tidak, mereka mencela dan memuji janda di saat yang bersamaan. Sikap ini menunjukkan karakter yang mendua dari masyarakat Minangkabau.

\section{PENUTUP}

Maota merupakan salah satu sarana dalam pembentukan stigma terhadap janda. Masyarakat memberikan dan mengukuhkan pandangan mereka terhadap janda dengan cara maotaan janda kepada orang lain di sekitarnya. Dengan mengamati kebiasaan maota, dapat diketahui bentuk-bentuk stigma masyarakat Minangkabau terhadap janda. Peneliti bisa melihat kepribadian dan karakter masyarakat Minangkabau dengan melakukan analisis terhadap stigma tersebut.

Stigma terhadap janda merupakan "jendela" yang peneliti gunakan untuk melihat realita masyarakat Minangkabau. Stigma terhadap janda merupakan refleksi dari karakter masyarakat Minangkabau. Bentukbentuk stigma yang mendua, seperti indak pandai balaki dan kacang ka lakilaki, tagak surang, dan jadi baban menegaskan bahwa masyarakat Minangkabau memiliki pandangan yang mendua dalam kehidupannya, 
Handep, Vol. 2, No. 1, Desember 2018

termasuk pandangan mereka terhadap janda.

\section{DAFTAR SUMBER}

Allport, Gordon W. dan Leo Postman. 1947. The Psychology of Rumour.

New York: Henry Holt and Company.

Arifin, Zainal. 2009. Dualitas Praktik Perkawinan Minangkabau. Humaniora. Vol. 21, No.2, hlm.150-161.

2012. Buru Babi: Politik Identitas Laki-Laki Minangkabau. Humaniora. Vol. 24, No.1, hlm. 2936.

Asri, Yasnur. 2013. Refleksi Ideologi Perempuan Minangkabau dalam Novel Negeri Perempuan Karya Wisran Hadi. Humaniora. Vol. 25, hlm. 69-81.

Goffman, Erving. 1963. Stigma and Social Identity: Stigma: Notes on the Management of Spoiled Identity, diunduh dari courses. washington.edu/intro $2 \mathrm{ds} /$ Readings7 Goffman-stigma.doc, pada November 2017.

Goldstein, Diane E. 2004. Once Upon a Virus: AIDS Legends and Vernacular Risk Perception. Logan, Utah: Utah State University Press.

Hakimy I. 1978. Pokok-Pokok Pengetahuan Adat Alam Minangkabau. Bandung: Remaja Rosdakarya.
Hurlock, Elizabeth B. 1980. Psikologi Perkembangan: Suatu Pendekatan Sepanjang Rentang Kehidupan. Jakarta: Gramedia.

Kalmre, Eda. 2013. The Human Sausage Factory: A Study of PostWar Rumour in Tartu, diunduh dari Http://www.researchgate.net/ publication/318-1-885Kalmre_Eda_The_Human_Sausage_ Factory_A_Study_of_Postwar_ Rumour_in_Tartu, pada tanggal 25 Desember 2017. . 2017 Introduction: The Social and Political Dynamic of Conspiracy Theories, Rumours, Fake News, and Belief Narrative, diunduh dari https:// www.researchgae.ne/publication/ 32023113Introduction The Social and Political Dynamic of Conspiracy Theories Rumours Fake Newsand Belief Narratives, pada 20 Januari 2018.

Kapferer, Jean-Noel 1990. Rumors: Uses, Interpretations, and Images. New Brunswick, NJ: Transaction.

Kuneifi, Ahmad. 2005. Kedudukan dan Peranan Laki-Laki Dalam Masyarakat Minangkabau Bukittinggi Perantauan di Jakarta Serta Pengaruhnya Terhadap Hukum Waris. Tesis. Semarang: Pasca-Sarjana Universitas Diponegoro.

Parker, Lyn. 2016. The Theory and Context of the Stigmatisation of 
Widows and Divorcees (Janda) in Indonesia. Indonesia and the Malay World 44, hlm.128, 7-26.

Saanin, H.H.B., Datuk Tan Pariaman. 1989. "Kepribadian Orang Minangkabau dan Psikopatologinya" dalam M.A.W. Brouwer (ed.). Kepribadian dan Perubahannya. Jakarta: Gramedia.

Selasih. 1989. Bundo Kanduang. Jakarta: Proyek Penerbitan Buku Sastra Indonesia dan Daerah.

Shibutani, Tamotsu 1966. Improvised News: A Sociological Study of Rumor. Indianapolis \& New York: Bobbs-Merill.

Sukmawati, Noni. 2006. Ratapan Perempuan Minangkabau dalam Pertunjukkan Bergurau. Gambaran Perubahan Sosial Minangkabau. Padang: Andalas University Press.

Wawancara. AB. Padang, 29 Mei 2017. BN. Padang, 18 Februari 2017. Informan. Padang, 25 Mei 2017. . MT. Padang, 30 Agustus 2017. . MH. Padang, 25 Mei 2017. . SLV. Padang, 18 Februari 2017. . TR. Padang, 20 Mei 2017. 
